JKM (Jurnal Kebidanan Malahayati),Vol 7,No.2.April 2021,

ISSN (Print) 2476-8944 ISSN (Online) 2579-762X, Hal 182-191

\title{
FAKTOR-FAKTOR YANG MEMPENGARUHI KELULUSAN UJI PRAKTIK ANTENATAL CARE PADA MAHASISWA TINGKAT I SEMESTER II AKADEMI KEBIDANAN
}

\author{
Illa Arinta* \\ "Akademi Kebidanan RSPAD Gatot Soebroto \\ email illa_arinta@akbidrspad.ac.id
}

\section{ABSTRACT FACTORS AFFECTING THE GRADUATION OF ANTHENATAL CARE PRACTICE TEST IN LEVEL I SEMESTER II STUDENTS OF MIDWIFERY ACADEMY}

Background. The success of students in higher education is influenced by several factors, both internal and external. Internal factors are factors that come from students themselves, such as learning motivation, learning attitudes and habits, learning skills, physical condition. External factors are factors that come from outside the students themselves, such as the family, school and community environment. The preliminary survey which was conducted by interviewing 10 students on August 1, 2019, as many as 8 students said that the practice of Antenatal Care is one of the tests that is rather difficult to understand because it was the first experience facing the exam so that the experience of the practical exams that had been carried out had not been described. Students also said that they rarely study independently in the laboratory because the steps to practice antenatal care are difficult to learn

Purpose knowing the factors that influence the graduation of antenatal care (ANC) practice in midwifery students semester II at the Midwifery Academy of the Gatot Soebroto Army Hospital in 2019.

Method. The research design used was quantitative by using a cross sectional approach, the research location was carried out at the Midwifery Academy of RSPAD Gatot Soebroto, with a total sample of 49 female students. Research time from March to August 2019. Univariate and bivariate data analysis using ChiSquare.

Result. Evaluation of the ANC practice exam in students is very good with the results of the psychological test still being suggested by 16 respondents $84.2 \%$. The results of most ANC practice exam evaluations are good with health tests fulfilling the requirements as many as 15 respondents $60.0 \%$. The results of the most evaluations of ANC practice exams are good results with 21 respondents $70.0 \%$ of the origin majoring in science. Most ANC practice exam evaluation results are with good results with guidance intensity> 3 times as many as 29 respondents $96.7 \%$.

Conclusion. ANC practice exam evaluation on students is very good with the results of the psychological test can still be suggested, there is a significant relationship between the ANC practice score and the psychological test. There is no significant relationship between ANC practice scores with health tests, high school majors and intensity of guidance.

Suggestions based on the results of the research show that the results of the psychological test have a very significant effect on academic achievement, therefore focusing on increasing the psychological factors of students is the most appropriate effort to improve and or maintain academic achievement. It is suggested to students to further increase their motivation to learn through various ways, including liking each subject presented, having a desire to acquire knowledge and others.

Key words: antenatal care, psychology test, students

\section{ABSTRAK}

Latar Belakang. Keberhasilan mahasiswa di perguruan tinggi dipengaruhi oleh beberapa faktor, baik internal maupun eksternal. Faktor internal merupakan faktor yang berasal dari diri mahasiswa itu sendiri, seperti motivasi belajar, sikap dan kebiasaan belajar, keterampilan belajar, kondisi fisik. Faktor eksternal merupakan faktor yang berasal dari luar diri mahasiswa itu sendiri, seperti lingkungan keluarga, sekolah dan masyarakat. Survey pendahuluan yang dilakukan dengan mewawancarai 10 mahasiswa pada tanggal 1 Agustus 2019 sebanyak 8 mahasiswa mengatakan bahwa praktik Antenatal Care merupakan salah satu ujian yang agak sulit dipahami karena pengalaman pertama kali menghadapi ujian sehingga belum tergambar pengalaman ujian praktik yang telah dilaksanakan. Mahasiswa juga mengatakan mereka jarang belajar mandiri di laboratorium karena langkah -langkah praktik antenatal care sulit untuk dipelajari 


\section{Illa Arinta}

Tujuan. Diketahuinya faktor-faktor yang mempengaruhi kelulusan praktik antenatal care (ANC) pada mahasiswa kebidanan semester II di Akademi Kebidanan RSPAD Gatot Soebroto Tahun 2019.

Metode. Desain penelitian yang digunakan adalah kuantitatif dengan meggunakan pendekatan cross sectional, lokasi penelitian dilaksanakan di Akademi Kebidanan RSPAD Gatot Soebroto, dengan jumlah sampel 49 mahasiswi. Waktu penelitian bulan Maret sampai dengan Agustus 2019.Analisa data univariat dan bivariate dengan ChiSquare.

Hasil. evaluasi ujian praktik ANC pada mahasiswa sangat baik dengan hasil tes psikotes masih dapat disarankan sebanyak 16 responden $84.2 \%$. Hasil evaluasi ujian praktik ANC terbanyak adalah baik dengan tes kesehatan memenuhi syarat sebanyak 15 responden $60.0 \%$. Hasil evaluasi ujian praktik ANC terbanyak adalah hasil baik dengan asal jurusan dari IPA sebanyak 21 responden $70.0 \%$. Hasil evaluasi ujian praktik ANC terbanyak adalah dengan hasil baik dengan intensitas bimbingan $>3$ kali sebanyak 29 responden $96.7 \%$.

Kesimpulan. evaluasi ujian praktik ANC pada mahasiswa sangat baik dengan hasil tes psikotes masih dapat disarankan, ada hubungan yang bermakna antara nilai praktik ANC dengan test psikotest. Tidak ada hubungan yang bermakna antara nilai praktik ANC dengan test kesehatan, jurusan SMA dan intensitas bimbingan.

Saran berdasarkan hasil penelitian, diketahui bahwa hasil test psikotest memiliki pengaruh yang sangat signifikan terhadap prestasi akademik, untuk itu fokus terhadap peningkatan faktor psikis mahasiswa merupakan usaha yang paling sesuai untuk meningkatkan dan atau mempertahankan prestasi akademik. disarankan kepada mahasiswa untuk lebih meningkatkan motivasi belajarnya melalui berbagai cara, antara lain menyukai tiap mata pelajaran yang disajikan, memiliki keinginan untuk memperoleh pengetahuan dan lain-lain.

Kata kunci : antenatal care, psikotest, mahasiswa

\section{PENDAHULUAN}

Belajar adalah sebuah proses usaha yang dilakukan seseorang untuk mendapatkan suatu perubahan tingkah laku yang baru secara keseluruhan, sebagai hasil pengalamannya sendiri dalam interaksi dengan lingkungannya. (Slameto, 2010).

Hasil belajar sebagai ukuran kemajuan belajar mahasiswa menurut Surat Keputusan Menteri Pendidikan Nasional Nomor 232/U/2002, tentang pedoman penyusunan Kurikulum Pendidikan Tinggi. Penilaian hasil belajar mahasiswa diukur secara berkala melalui ujian tengah semester dan ujian semester. Dari mata kuliah yang diajarkan, terdapat beberapa mata kuliah dengan nilai yang kurang memuaskan, salah satunya mata kuliah Asuhan Antenatal Care (ANC) khususnya uji praktek ANC.

Menjadi biidan yang kompeten, dibutuhkan proses pendidikan dan pengajaran yang profesional dalam ilmu kebidanan. Pada umumnya mahasiswa bidan melewati tahapan pendidikan akademik secara teori serta memenuhi tuntutan praktikum untuk mengembangkan keterampilan teori yang diperolehnya sehingga berhak lulus dan mendapat gelar AmdKeb (Nursalam dan Effendy, 2008).

Bagi mahasiswa program studi kebidanan, adanya metode pembelajaran PBL (Problem-Based Learning) menuntut pendidikan yang penuh kompetensi dan praktek klinik yang ketat, sehingga tidak jarang mahasiswa mengalami stres.
Umumnya, kesulitan-kesulitan yang ada berkaitan dengan masalah interpersonal, perasaan frustasi dan perasaan lelah yang muncul pada saat kebutuhan mahasiswa tidak teridentifikasi dengan baik, serta situasi nyata di lapangan yang tidak sekedar menggambarkan situasi di teori (Nursalam dan Effendy, 2008).

Proses belajar akan berlangsung dengan baik, apabila mahasiswa aktif. Bahwa segala pengetahuan dan keterampilan harus diperoleh sendiri melalui pengamatan, pengalaman, penyelidikan, dengan bekerja sendiri dan fasilitas yang diciptakan sendiri dalam hal kegiatan belajar meliputi keaktifan praktikum peserta didik di laboratorium.(Wijaya,2015). Keaktifan praktikum meliputi persiapan fisik dan mental dalam persiapan ujian Antenatal Care sangat diperlukan untuk menentukan kemampuan mengaplikasikan tindakan asuhan kebidanan pada ibu hamil sesuai dengan standar praktik bidan. (Sardiman, 2012)

Model pembelajaran/metode merupakan strategi yang digunakan untuk meningkatkan motivasi belajar, sikap belajar di kalangan siswa, mampu berpikir kritis, memiliki keterampilan sosial dan pencapaian hasil belajar yang lebih optimal. Berbagai metode dapat digunakan oleh pendidik untuk meningkatkan pemahaman mahasiswa dalam proses belajar mengajar, salah satu metode yang digunakan pendidik dalam pembelajaran adalah metode praktik (Isjoni, 2009). 
JKM (Jurnal Kebidanan Malahayati),Vol 7,No.2.April 2021,

ISSN (Print) 2476-8944 ISSN (Online) 2579-762X, Hal 182-191

Survey pendahuluan yang dilakukan dengan mewawancarai 10 mahasiswa pada tanggal 1 Agustus 2019 sebanyak 8 mahasiswa mengatakan bahwa praktik Antenatal Care merupakan salah satu ujian yang agak sulit dipahami karena pengalaman pertama kali menghadapi ujian sehingga belum tergambar pengalaman ujian praktik yang telah dilaksanakan. Mahasiswa juga mengatakan mereka jarang belajar mandiri di laboratorium karena langkah -langkah praktik antenatal care sulit untuk dipelajari.

\section{METODE PENELITIAN}

Penelitian ini menggunakan metode deskriptif analitik cross sectional yaitu suatu penelitian dengan melakukan pengamatan antara faktor-faktor yang mempengaruhi dengan resiko atau efek, dengan cara pendekatan, observasi dan mengumpulkan data dalam satu kali waktu pada waktu bersamaan.

Tehnik pengumpulan data dilakukan melalui pengamatan pada parameter antara lain, nilai uji tulis, Hasil tes kesehatan, Hasil tes psikotes, Jumlah bimbingan dengan pembimbing akademik, Jurusan asal sekolah, Nilai praktik anc. Data yang dikumpulkan berupa data mahasiswa baru tahun akademik 2018/2019 yang diperoleh dari Bagian Akademik Akademi Kebidanan RSPAD Gatot Soebroto Sampel penelitian ini 49 mahasiswa Tingkat I semester II. Waktu Penelitian bulan Maret sampai Agustus 2019.Analisa data dengan univariat dan bivariate dengan chi square. Hasil penelitian dianalisis dengan menggunakan SPPS.

\section{HASIL PENELITIAN \\ Nilai antenatal care}

Tabel 1.

Distribusi Frekuensi Nilai Praktik Antenatal Care (ANC)

\begin{tabular}{ccc}
\hline Nilai ANC & Frekuensi & Persentase \% \\
\hline Sangat Baik & 17 & 34,7 \\
Baik & 32 & 65,3 \\
\hline Jumlah & 49 & 100 \\
\hline
\end{tabular}

Berdasarkan tabel diatas dapat disimpulkan bahwa dari 49 mahasiwa dengan nilai ANC sangat baik sejumlah $17(34,7 \%)$, sedangkan dengan nilai baik sejumlah $32(65,3)$.

Nilai uji psikotest

Tabel 2.

Distribusi Frekuensi Nilai uji psikotest

Nilai uji psikotest $\quad$ Frekuensi Persentase

\begin{tabular}{ccc}
\hline & & $\%$ \\
\hline Masih dapat disarankan & 31 & $63,3 \%$ \\
Tidak dapat disarankan & 18 & $36,7 \%$ \\
\hline Jumlah & 49 & 100 \\
\hline
\end{tabular}

Hasil penelitian bahwa dari 49 mahasiwa dengan nilai uji psikotest dengan hasil Masih dapat disarankan sejumlah 31 (63,3\%), sedangkan dengan nilai Tidak dapat disarankan sejumlah 18 $(36,7 \%)$.

\section{Nilai test kesehatan}

Tabel 3.

Distribusi Frekuensi Nilai test kesehatan

\begin{tabular}{lcc}
\hline Nilai test kesehatan & Frekuensi & $\begin{array}{c}\text { Persentase } \\
\%\end{array}$ \\
\hline Memenuhi syarat & 26 & $53,1 \%$ \\
Tidak Memenuhi Syarat & 23 & $46,9 \%$ \\
\hline Jumlah & 49 & 100 \\
\hline
\end{tabular}

Hasil penelitian bahwa dari 49 mahasiwa dengan nilai test kesehatan dengan hasil memenuhi syarat sejumlah $26(53,1 \%)$, sedangkan dengan nilai tidak memenuhi syarat sejumlah $23(46,9 \%)$.

\section{Jurusan saat SMA}

Tabel 4.

Distribusi Frekuensi jurusan saat SMA

\begin{tabular}{|c|c|c|}
\hline Nilai test kesehatan & Frekuensi & $\begin{array}{c}\text { Persentase } \\
\%\end{array}$ \\
\hline IPA, SMK kesehatan & 37 & $75,5 \%$ \\
\hline IPS & 12 & $24,5 \%$ \\
\hline Jumlah & 49 & 100 \\
\hline
\end{tabular}

Hasil penelitian bahwa dari 49 mahasiwa dari jurusan IPA, SMK kesehatan sejumlah 37 $(75,5 \%)$, sedangkan dari jurusan IPS sejumlah 12 $(24,5 \%)$.

\section{Bimbingan ANC}

Tabel 5.

Distribusi Frekuensi Bimbingan ANC

\begin{tabular}{ccc}
\hline Bimbingan ANC & Frekuensi & Persentase $\%$ \\
\hline$\geq 3 x$ & 4 & $18,4 \%$ \\
$<3 x$ & 45 & $81,6 \%$ \\
\hline Jumlah & 49 & 100 \\
\hline
\end{tabular}

Hasil penelitian dari 49 mahasiwa sering bimbingan ANC sejumlah $4(18,4 \%)$ dan yang jarang sejumlah $45(81,6 \%)$. 
Tabel 6

Hubungan Nilai Praktik Antenatal Care (ANC) Dengan tes psikotes

\begin{tabular}{|c|c|c|c|c|}
\hline \multirow{2}{*}{ Tes Psikotes } & \multicolumn{2}{|c|}{ Nilai Praktik ANC } & \multirow{2}{*}{$\begin{array}{c}\text { Total } \\
\mathrm{N}=49(100 \%)\end{array}$} & \multirow{2}{*}{$\begin{array}{c}P \\
\text { value }\end{array}$} \\
\hline & Sangat baik & Baik & & \\
\hline Masih dapat disarankan & $\begin{array}{c}16 \\
84.2 \%\end{array}$ & $\begin{array}{c}15 \\
50.0 \%\end{array}$ & $\begin{array}{c}31 \\
63.3 \%\end{array}$ & 1 \\
\hline Tidak dapat disarankan & $\begin{array}{c}3 \\
15.8 \%\end{array}$ & $\begin{array}{c}15 \\
50.0 \%\end{array}$ & $\begin{array}{c}18 \\
36.7 \%\end{array}$ & 0,034 \\
\hline
\end{tabular}

Hasil evaluasi ujian praktik ANC pada mahasiswa sangat baik dengan hasil tes psikotes masih dapat disarankan sebanyak 16 responden
$84.2 \%$. Ada hubungan yang bermakna antara nilai praktik ANC dengan test psikotest.

Tabel 7.

Hubungan Nilai Praktik Antenatal Care (ANC) Dengan tes kesehatan

\begin{tabular}{|c|c|c|c|c|}
\hline \multirow{2}{*}{ Tes kesehatan } & \multicolumn{2}{|c|}{ Nilai Praktik ANC } & \multirow{2}{*}{$\begin{array}{c}\text { Total } \\
\mathrm{N}=49(100 \%)\end{array}$} & \multirow{2}{*}{$P$ value } \\
\hline & Sangat baik & Baik & & \\
\hline Memenuhi syarat & $\begin{array}{c}9 \\
47.4 \%\end{array}$ & $\begin{array}{c}15 \\
60.0 \%\end{array}$ & $\begin{array}{c}31 \\
55.1 \%\end{array}$ & \\
\hline Tidak Memenuhi Syarat & $\begin{array}{c}10 \\
52.6 \%\end{array}$ & $\begin{array}{c}12 \\
40.0 \%\end{array}$ & $\begin{array}{c}18 \\
44.9 \%\end{array}$ & 0,568 \\
\hline
\end{tabular}

Hasil Tes Kesehatan memenuhi syarat dengan nilai praktik ANC sangat baik sebesar
47.4\%. tidak Ada hubungan yang bermakna antara nilai praktik ANC dengan hasil test kesehatan.

Tabel 8.

Hubungan Nilai Praktik Antenatal Care (ANC) Dengan Jurusan SMA

\begin{tabular}{lcccc}
\hline \multirow{2}{*}{ Jurusan SMA } & \multicolumn{2}{c}{ Nilai Praktik ANC } & Total & \multirow{2}{*}{ P value } \\
\cline { 2 - 3 } & Sangat baik & Baik & $\mathbf{N 9}(\mathbf{1 0 0} \%)$ & \\
\hline \multirow{2}{*}{ IImu Pengetahuan Alam(IPA) } & 16 & 21 & 37 & \\
\multirow{2}{*}{ IImu Pengetahuan Sosial (IPS) } & $84.2 \%$ & $70.0 \%$ & $74.5 \%$ & \multirow{2}{*}{0,432} \\
& 3 & 9 & 12 & \\
\hline
\end{tabular}

Asal jurusan saat SMA dengan nilai praktik ANC sangat baik sebesar $84.2 \%$. tidak Ada hubungan yang bermakna antara nilai praktik ANC dengan asal jurusan saat SMA.

Tabel 9.

Hubungan Nilai Praktik Antenatal Care (ANC) Dengan Intensitas Bimbingan

\begin{tabular}{|c|c|c|c|c|}
\hline \multirow{2}{*}{ Intensitas bimbingan } & \multicolumn{2}{|c|}{ Nilai Praktik ANC } & \multirow{2}{*}{$\begin{array}{c}\text { Total } \\
\mathrm{N}=49(100 \%)\end{array}$} & \multirow{2}{*}{$P$ value } \\
\hline & Sangat baik & Baik & & \\
\hline$\geq 3$ Kali & 3 & 1 & 4 & \\
\hline$<3$ kali & $\begin{array}{c}15.8 \% \\
16 \\
84.2 \%\end{array}$ & $\begin{array}{c}3.3 \% \\
29 \\
96.7 \%\end{array}$ & $\begin{array}{c}8.2 \\
45 \\
91.8 \%\end{array}$ & 0,310 \\
\hline
\end{tabular}




\section{JKM (Jurnal Kebidanan Malahayati),Vol 7,No.2.April 2021, ISSN (Print) 2476-8944 ISSN (Online) 2579-762X, Hal 182-191}

Hasil evaluasi ujian praktik ANC pada mahasiswa sangat baik dengan intensitas bimbingan $\geq 3$ kali sebanyak $15.8 \%$. tidak Ada hubungan yang bermakna antara nilai praktik ANC dengan intensitas bimbingan.

\section{PEMBAHASAN}

\section{Hubungan Nilai Praktik Antenatal Care (ANC) Dengan tes psikotes}

Hasil evaluasi ujian praktik ANC pada mahasiswa sangat baik dengan hasil tes psikotes masih dapat disarankan sebanyak 16 responden $84.2 \%$. Ada hubungan yang bermakna antara nilai praktik ANC dengan test psikotest.

Hasil penelitian Hikmawati, dkk (2011) menunjukan bahwa kecerdasan intelektual dan psikologi seseorang memiliki pengaruh yang cukup signifikan terhadap prestasi belajar. Hal tersebut terjadi karena kecerdasan intelektual dan psikologi seseorang memiliki pengaruh yang signifikan terhadap kecepatan dan efektivitas mahasiswa dalam memproses bahan ajar yang diberikan kepadanya. Mahasiswa yang mempunyai taraf kecerdasan yang rendah akan mengalami kesulitan didalam menangkap, memahami, dan menyimpan informasi yang disampaikan oleh dosennya. Selain itu juga akan mengalami kesulitan didalam menganalisis, membayangkan, dan melakukan penilaian secara logis dan akurat sehingga secara tidak langsung prestasi belajar yang diperolehnya tidak akan maksimal.

Dalam proses belajar mengajar di perguruan tinggi sering ditemukan mahasiswa yang tidak memperoleh prestasi belajar yang setara dengan kemampuan intelegensinya.(Hastuti,2014). Ada mahasiswa yang mempunyai kemampuan intelegensi tinggi tetapi memperoleh prestasi yang rendah, namun ada mahasiswa yang walaupun kemampuan intelegensinya relative rendah, dapat meraih prestasi belajar yang relative tinggi. Itu sebabnya taraf intelegensi bukan merupakan satu satunya faktor yang menentukan keberhasilan seseorang karna ada faktor lain yang mempengaruhi salah satunya adalah faktor psikologis.(Gunawan,2016)

Prestasi seseorang ditentukan oleh faktor eksternal maupun internal. Berdasarkan faktor eksternal prestasi seseorang dipengaruhi oleh status sosial dan ekonomi, fasilitas pendidikan, dukungan orang tua, guru, maupun figur lainnya. Dari faktor internal/ personal sendiri terdapat faktor psikologis, yang menggerakkan seseorang untuk berprestasi (musthaq, I. \& Khan, S.N., 2012) seseorang yang memiliki tujuan dan disertai dengan motivasi, akan memiliki dorongan dalam dirinya sehingga akan bertindak untuk memenuhi dorongan tersebut dan melakukan usaha untuk mencapai hasil atau tujuan yang diinginkannya.

Psikologis seseorang berpengaruh terhadap motivasi serta penampilan siswa dalam meraih prestasi mereka. Psikologis mempengaruhi prestasi seseorang secara berbeda - beda pada tiap individu melalui variasi dari kualitas proses kognitif yang berupa regulasi diri masing - masing individu tersebut. Regulasi diri mengacu pada bagaimana siswa aktif terlibat dalam kegiatan - kegiatan belajar mereka, perencanaan, maupun mobilisasi sumber daya yang mereka miliki untuk memenuhi tuntutan penugasan tersebut, serta memantau performa mereka terhadap penyelesaian tugas tersebut, sehingga faktor personal atau psikologis mempengaruhi kualitas, waktu, dan strategi kognitif yang tepat untuk mengontrol kualitas prestasi seseorang (Ahmadi, 2009)

Akademi kebidanan RSPAD Gatot Soebroto dilakukan bermacam tes untuk memastikan bahwa mahasiswa yang akan diterima mampu mengikuti kegiatan perkuliahan dengan baik dan mampu mencapai prestasi belajar yang optimal. Salah satu tes yang dilakukan adalah tes psikotes atau lebih dikenal dengan istilah psikotes. Psikotes (tes psikologi) bertujuan untuk mengukur kondisi seseorang dalam hal kejiwaan dan potensi serta kemampuan khusus.Kecerdasan emosional merupakan suatu hal yang dapat dipelajari dan bukan sifat bawaan.(Dewi,2012)

Pengukuran beberapa aspek tersebut diatas merupakan usaha yang sangat penting dalam memprediksi kemampuan atau potensi yang dimiliki seseorang sesuai dengan persyaratan yang ditentukan oleh institusi sebagai tempat mahasiswa tersebut menimbah ilmu

Pengukuran psikologis dalam psikotes memiliki makna yang luas, dan pada umumnya dipakai sebagai second opinion dari technical test. Hasil pengkuran psikologis adalah gambaran instan dari sisi aspek : kecerdasan, sikap kerja, dan kepribadian. (Syaiful, 2011)

\section{Hubungan Nilai Praktik Antenatal Care (ANC) Dengan tes kesehatan}

Hasil Tes Kesehatan memenuhi syarat dengan nilai praktik ANC sangat baik sebesar $47.4 \%$. tidak Ada hubungan yang bermakna antara nilai praktik ANC dengan hasil test kesehatan.

Elemen fisik (materi , tubuh) paling mudah dipahami, mudah dikenali oleh pancaindra manusia. Elemen fisik mencakup segala yang kasat mata (dunia fisik maupun tubuh fisik). Tubuh (fisik) manusia merupakan sistem yang luar biasa yang 
terbentuk dari triliunan sel-sel. Sel-sel ini membentuk berbagai jaringan yang sangat rumit tapi semua jaringan ini di samping berfungsi sendirisendiri, juga mampu melakukan kerja sama dan koordinasi antar jaringan dengan kecermatan yang sangat tinggi (Chopra, 2004).

Dengan demikian, sel-sel tubuh manusia ini juga mempunyai kecerdasan, mengatakan bahwa jantung memiliki kekuatan khusus yang sanggup menyimpan berbagai informasi dan mengobati sekaligus. Ini menunjukkan bahwa daya ingat bukan hanya di otak saja, tetapi jantung pun terkadang menjadi penggerak dan pengendali daya ingat tersebut. (chopra, 2004) schwartz (dalam alkusayer,2009)

Tubuh manusia merupakan seperangkat mesin cerdas yang mengalahkan bahkan komputer secanggih sekalipun. Walaupun elemen fisik ( tubuh) manusia merupakan mesin yang luar biasa, namun hampir semua kondisi ketahanan/kesehatan fisik jangka panjang ditentukan oleh hasil dari tingkah laku dan kebiasaan-kebiasaan setiap orang yang telah terakumulasi selama beberapa waktu. (Covey, 2005).

Faktor-faktor yang mempengaruhi prestasi akademik dalam banyak hal sering saling berkaitan dan mempengaruhi satu sama lain. Seorang siswa yang bersikap conserving terhadap ilmu pengetahuan atau bermotifekstrinsik (faktor eksternal)(Syarifuddin,2011). umpamanya, biasanya cenderung mengambil pendekatan belajar yang sederhana dan tidak mendalam. Sebaliknya, seorang siswa yang berintelegensi tinggi (faktorinternal) dan mendapat dorongan positif dari orang tuanya (faktor eksternal), mungkin akan memilih pendekatan belajar yang lebih mementingkan kualitas hasil belajar.(Kadrianti,2020)

Jadi, karena pengaruh faktor-faktor tersebut, muncul siswa-siswa yang berprestasi tingi dan berprestasi rendah atau gagal sama sekali. Dalam hal ini, seorang guru yang kompeten dan profesional diharapkan mampu mengantisipasi kemungkinan -kemungkinan munculnya kelompok siswa yang menunjukkan gejala kegagalan dengan berusaha mengetahui dan mengatasi faktor yang menghambat proses belajar mereka.(Madhah,2016)

Hal ini juga didukung penelitian menunjukkan bahwa ada faktor-faktor lain yang mempengaruhi prestasi akademik. mengatakan bahwa iklim kelas berkorelasi positif dengan perubahan tingkah laku dan prestasi hasil pembelajaran siswa. (Arini,2008). Dengan kata lain, iklim kelas merupakan salah satu cara untuk meningkatkan efektifitas dan kualitas pembelajaran di kelas. Iklim kelas merupakan faktor ekternal yang dapat mempengaruhi prestasi akademik siswa. Iklim kelas sendiri meliputi ruangan kelas, lingkungan kelas (Tarmidi, 2006)

\section{Hubungan Nilai Praktik Antenatal Care (ANC) Dengan Jurusan SMA}

Asal jurusan saat SMA dengan nilai praktik ANC sangat baik sebesar $84.2 \%$. tidak Ada hubungan yang bermakna antara nilai praktik ANC dengan asal jurusan saat SMA

Bagi siswa yang ingin melanjutkan studi ke perguruan tinggi, Sekolah Menengah Atas (SMA) adalah sekolah yang dapat menjadi masa persiapan yang baik. Hal ini disebabkan program penjurusan biasanya dimulai dibangku Sekolah Menengah Atas. Jika dilihat dari struktur kurikulumnya, kurikulum Sekolah Menengah Atas mencakup dua jenis yaitu struktur kurikulum program studi dan struktur kurikulum program pilihan. Struktur kurikulum program pilihan adalah dimaksudkan untuk memberikan kebebasan kepada peserta didik dalam memilih sejumlah mata pelajaran yang sesuai potensi, bakat, dan minat peserta didik (Purnama, 2010)

keunggulan Sekolah Menegah Atas (SMA) khsusunya adalah dalam penguasaan konsep, cara berpikir, performance sebagai bekal ke pendidikan berikutnya. Sekolah Menengah Atas (SMA) memang disiapkan untuk meneruskan ke jenjang yang lebih tinggu, yaitu bangku perkuliahan (Siswoyo, 2008)

Sekolah Menengah Kejuruan (SMK) adalah salah satu jenis pendidikan menengah di Indonesia. Sekolah kejuruan statusnya sama dengan Sekolah Menengah Atas. Sekolah kejuruan memiliki jurusan yang lebih bervariasi dibandingkan dengan Sekolah Menengah Atas dan pilihan jurusan itu nantinya akan berhubungan juga dengan jenis pekerjaan. Oleh, karena itu, siswa yang memilih untuk langsung bekerja, Sekolah Menengah Kejuruan adalah pilihan yang tepat. Hal ini disebabkan karena muatan materinya memang dipersiapkan agar siswanya kelak siap memasuki dunia kerja/professional (Purnama, 2010)

Asal sekolah merupakan perbedaan yang ada hubungannya atau bernilai tinggi pada hasil akhir presentasi belajar, dimana kemajuan sekolah juga mempengaruhi proses pembelajaran yang ditempuh selama perkuliahan, jika anak tersebut sudah biasa mendapat pelajaran ataupun kegiatan ekstra pada saat menempuh sekolah menengah maka mahasiswa tersebut akan menerima pelajaran saat perkuliahan berlangsung. Selama ini yang banyak diminati anak untuk masuk kesehatan yaitu 


\section{JKM (Jurnal Kebidanan Malahayati),Vol 7,No.2.April 2021, ISSN (Print) 2476-8944 ISSN (Online) 2579-762X, Hal 182-191}

berasal dari SMA. Namun saat ini tidak hanya dari SMA saja namun MA juga diminati. Namun untuk saat ini tidak kalah pesatnya banyak lulusan SMK yang juga masuk kesehatan. (Purnama, 2010)

Beragamnya asal jurusan mahasiswa akan berdampak pada pemahaman mata kuliah yang didapatkan di Akademi, terutama pada semester awal. Dimana mata kuliah semester awal bersifat umum/dasar di samping itu perlu juga banyak adaptasi dengan mata kuliah tentang kebidanan (Siswoyo, 2008)

Beragamnya asal jurusan mahasiswa akan berdampak pada pemahaman mata kuliah yang didapatkan di akademi, terutama pada semester awal. Dimana mata kuliah semester awal bersifat umum/dasar (materi yang didapat pada saar sekolah di SMA/SMK) di samping itu perlu banyak adaptasi dengan mata kuliah tentang kebidanan. (Siswoyo, 2008)

\section{Hubungan Nilai Praktik Antenatal Care (ANC) Dengan Intensitas Bimbingan}

Hasil evaluasi ujian praktik ANC pada mahasiswa sangat baik dengan intensitas bimbingan $\geq 3$ kali sebanyak $15.8 \%$. tidak Ada hubungan yang bermakna antara nilai praktik ANC dengan intensitas bimbingan.

Bimbingan akademik bertujuan untuk membantu mahasiswa dalam menghadapi dan memecahkan masalah masalah dalam bidang pendidikan pada khususnya. (Suranata,2013). Bimbingan akademik berkaitan dengan kegiatan pendidikan, maka persoalan yang muncul terutama dari mahasiswa sendiri sebagai peserta didik seperti pengaturan waktu belajar yang efektif, memilih metode belajar yang tepat, menggunakan bukubuku pelajaran bahasa inggris, cara belajar dalam kelompok, mempersiapkan ujian, memilih mata pelajaran yang cocok dan sebagainya.(Ahmad,2018)

Sesuai dengan hal tersebut maka bimbingan akademik memberikan bantuan kepada mahasiswa dalam hal kesulitan dalam belajar sehingga dapat meningkatkan prestasi mahasiswa. dalam proses pembelajaran tanggung jawab pencapaian tujuan belajar selain terletak pada mahasiswa juga pada pembimbing akademik. (Sunarsih,2009).Peran pembimbing sebagai motifator merupakan salah satu aspek yang sangat penting untuk mencapai keberhasilan dalam pembelajaran, dengan demikian mahasiswa termotivasi untuk melaksanakan dan mencapai tujuan pembelajaran selama menempuh pendidikan. Membantu mahasiswa agar dapat mengembangkan sikap dan kebiasaan belajar yang baik (Slamet, 2010).

Menurut Lieskusumastuti 2018 Keaktifan praktikum Mahasiswa mayoritas termasuk kategori tinggi sebanyak 32 responden $(88,2 \%)$. Hasil evaluasi ujian ANC Mahasiswa mayoritas termasuk kategori baik sebanyak 16 responden (47,1\%). Ada hubungan signifikan antara keaktifan praktikum dengan hasil evaluasi ujian ANC Pada Mahasiswa Prodi DIII Kebidanan STIKES Mamba'ul 'Ulum Surakarta yaitu dengan nilai $p(0,000)<0,005$. Ada hubungan signifikan antara keaktifan praktikum dengan hasil evaluasi ujian ANC Pada Mahasiswa Prodi DIII Kebidanan STIKES Mamba'ul 'Ulum Surakarta.

Hasil ini juga sesuai dengan pendapat siswoharjono dalam ilyas (2009) yang mengatakan bahwa salah satu peran pembimbing adalah untuk memberi motivasi belajar kepada bimbingannya sesuai dengan kebutuhan masing-masing mahasiswa.(Suryati) Pembimbing akademik harus mampu menjadi motivator bagi mahasiswa pembimbingnya, sehingga apabila pembimbing akademik telah menjalankan peran dan fungsinya dengan baik diharapkan dapat memberi kontribusi terhadap peningkatan motivasi belajar mahasiswa.(Wardana 2017)

Faktor yang mempengaruhi pembimbing akademik tidak dapat menjalankan peran dan tugasnya dikarenakan hampir semua dosen mempunyai tugas rangkap yang lebih dari satu yaitu sebagai jabatan administratif, struktural, dan fungsional.(Afrianti,2014) Selain itu juga tugas tri darma dosen yaitu sebagai peneliti, pengajar dan pembimbing yang salah satunya tugas menjadi pembimbing praktik klinik serta mempunyai tugas sebagai pengabdi pelayan masyarakat, pengalaman pribadi yang menjadi dasar pembentukan sikap dan perilaku yang berbedabeda terhadap mahasiswa bimbingannya, pengaruh orang lain yang dianggap penting misalnya pimpinan, ketua, budaya kerja, media sosial dan faktor bnayak fikiran atau stress. (Siwi,2011)

\section{SIMPULAN}

Hasil evaluasi ujian praktik ANC pada mahasiswa sangat baik dengan hasil tes psikotes masih dapat disarankan sebanyak 16 responden $84.2 \%$. Ada hubungan yang bermakna antara nilai praktik ANC dengan test psikotest.dan tidak ada hubungan hasil evaluasi praktik ANC dengan hasil test kesehatan, asal jurusan SMA, dan intensitas bimbingan.

\section{SARAN}


Berdasarkan hasil penelitian, diketahui bahwa hasil test psikotest memiliki pengaruh yang sangat signifikan terhadap prestasi akademik, untuk itu fokus terhadap peningkatan faktor psikis mahasiswa merupakan usaha yang paling sesuai untuk meningkatkan dan atau mempertahankan prestasi akademik. disarankan kepada mahasiswa untuk lebih meningkatkan motivasi belajarnya melalui berbagai cara, antara lain menyukai tiap

\section{DAFTAR PUSTAKA}

Afrianti, V., \& Hidayat, A. (2014). Hubungan Peran Pembimbing Akademik dengan Motivasi Belajar Mahasiswa D III Kebidanan Semester IV STIKES 'Aisyiyah Yogyakarta (Doctoral dissertation, STIKES'Aisyiyah Yogyakarta).

Ahmad Susanto, M. P. (2018). Bimbingan dan konseling di Sekolah: Konsep, teori, dan aplikasinya. Kencana.

Ahmadi, A. (2019). Psikologi Umum, Edisi Revisi 2009.

Arini, N. K. S., \& Fakhrurrozi, M. (2008). Pengaruh Tingkat Intelegensi dan Motivasi Belajar terhadap Prestasi Akademik Siswa Kelas II SMA Negeri 99 Jakarta. Unpublished Laporan Penelitian. Jakarta: Universitas Gunadarma.

Chopra, D. (2004). The Spontaneous Fulfillment of Desire, alih bahasa Arvin Saputra. Batam Centre: Karisma Publishing Group.

Covey, S. R. (2005). The 8th Habit, alih bahasa Wandi S. Brata, Jakarta: PT Gramedia.

Dewi, Y. K. (2012). Hubungan kecerdasan emosional dengan prestasi belajar antenatal care (anc).

Gunawan, I., Suraya, S. N., \& Tryanasari, D. (2016). Hubungan kemampuan berpikir kreatif dan kritis dengan prestasi belajar mahasiswa pada matakuliah konsep sains II prodi PGSD IKIP PGRI MADIUN. Premiere Educandum: Jurnal Pendidikan Dasar dan Pembelajaran, $4(01)$.

Hastuti, P. (2014). Deskripsi Kecerdasan Emosional dan Prestasi Belajar Mahasiswa Politeknik Kesehatan Kemenkes Semarang. Jurnal Kebidanan, 3(7), 52-55.

Hikmawati, F. (2011). Bimbingan Konseling Edisi Revisi. Jakarta: PT. RajaGrafindo Persada.

http://jurnal.unimed.ac.id/2012/index.php/jmpi/article /view/7859.

Hubungan Keaktifan Praktikum dengan Hasil Evaluasi Ujian Antenatal Care pada Mahasiswa Prodi DIII Kebidanan STIKES mata pelajaran yang disajikan, memiliki keinginan untuk memperoleh pengetahuan dan lain-lain.

Mamba'ul 'Ulum Surakarta. Avicenna: Journal of Health Research, 1(1).

Indriyani, R. (2014). Pengaruh Asal Sekolah Dan Tempat Tinggal Terhadap Prestasi Belajar Mahasiswa Prodi D III Kebidanan Universitas Wiraraja Sumenep (Doctoral dissertation, UNS (Sebelas Maret University)).

Isjoni, H. (2009). Pembelajaran kooperatif meningkatkan kecerdasan komunikasi antar peserta didik. Yogyakarta: Pustaka Pelajar.

Kadrianti, E., Kadir, A., \& Ilham, M. (2020). HUBUNGAN MOTIVASI MENJADI PERAWAT DENGAN INDEKS PRESTASI KUMULATIF (IPK) MAHASISWA TINGKAT II DI AKPER MAPPA OUDANG MAKASSAR. Jurnal IImiah Kesehatan Diagnosis, 15(3), 300-305.

Lieskusumastuti, A. D., \& Riawati, D. (2018).

Madihah, H. (2016). PENGARUH TINGKAT INTELEGENSI DAN MOTIVASI BELAJAR TERHADAP PRESTASI AKADEMIK SISWA KELAS XI SMA MUHAMMADIYAH 1 BANJARMASIN. AL'ULUM, 54(4).

Nursalam \& Efendi, F (2008). Pendidikan Dalam Keperawatan. Jakarta : Salemba Medika.Purnama, Dian.2010.Cermat Memilih Sekolah Menengah Atas.Jakarta: Gagasmedia

Sardiman, A.M. 2012. Interaksi Dan Motivasi Belajar Mengajar. Jakarta : Rajawali Pers.

Siswoyo, D. (2008). Arti Pendidikan dan Batasbatas Pendidikan. Ilmu Pendidikan.

Siwi, R. P. Y. (2011). Pengaruh Persepsi Tentang Lingkungan Belajar, Motivasi dan Persepsi Tentang Kepemimpinan Institusi Terhadap Prestasi Belajar Mahasiswa D III Kebidanan Stikes Nurul Jadid Probolinggo Dibandingkan dengan Akbid Mamba'ul Ulum Surakarta (Doctoral dissertation, UNS (Sebelas Maret University)).

Slameto, Belajar dan Faktor-faktor yang Mempengaruhinya, (Jakarta: PT Rineka Cipta, 2003), Cet. 4 h. 54-59 
JKM (Jurnal Kebidanan Malahayati),Vol 7,No.2.April 2021,

ISSN (Print) 2476-8944 ISSN (Online) 2579-762X, Hal 182-191

Sunarsih, T. (2009). Hubungan antara motivasi belajar, kemandirian belajar dan bimbingan akademik terhadap prestasi belajar mahasiswa di Stikes A. Yani Yogyakarta (Doctoral dissertation, UNS (Sebelas Maret University)).

Suranata, K. (2013). Pengembangan model tutor bimbingan konseling sebaya (peer counseling) untuk mengatasi masalah mahasiswa Fakultas IImu Pendidikan Undiksha. JPI (Jurnal Pendidikan Indonesia), 2(2).

Suriyati, S., \& Deni, M. HUBUNGAN PERAN PEMBIMBING AKADEMIK DENGAN MOTIVASI BELAJAR MAHASISWA DIV BIDAN PENDIDIK SEKOLAH TINGGI KESEHATAN TRI MANDIRI SAKTI BENGKULU TAHUN 2011. JURNAL KESEHATAN POLTEKKES PROVINSI BENGKULU, 1(2), 205-216.

Syaiful Bahri Djamarah, Psikologi Belajar, (Jakarta: PT Rineka Cipta, 2011)

Syarifuddin, A. (2011). Penerapan model pembelajaran cooperative belajar dan faktorfaktor yang mempengaruhinya. Ta'dib: Jurnal Pendidikan Islam, 16(01), 113-136.

Tanjung, R. D. S. FAKTOR-FAKTOR YANG MEMPENGARUHI HASIL BELAJAR ASUHAN ANTENATAL CARE (ANC) DI AKADEMI KEBIDANAN. JURNAL MANAJEMEN PENDIDIKAN INDONESIA, 8(1), 26-36.

Tarmidi. (2006). Iklim kelas dan prestasi belajar. Medan: Fakultas

Wardana, S. W., \& Soerjoasmoro, M. A. (2017). Hubungan peranan pembimbing akademik dengan stres pada siswa tahun pertama di Sekolah Menengah Atas A (Doctoral dissertation, Trisakti University).

Wijaya, R. S. (2015). Hubungan Kemandirian dengan Aktivitas Belajar Siswa. Jurnal Penelitian Tindakan Bimbingan \& Konseling, 1(3).

Wulansari, F. C. (2010). Hubungan Asal Jurusan Dengan Prestasi Belajar Mahasiswa Tingkat II Di Akademi Kebidanan Estu Utomo Boyolali Tahun 2010. Jurnal Komunikasi Kesehatan (Edisi 1), 1(01), 15-20. 